by Vikram C. Thakur ${ }^{+}$, M. Joshi ${ }^{2}$, N. Suresh ${ }^{1}$

\title{
Linking the Kangra piggy-back Basin with reactivation of the Jawalamukhi Thrust and erosion of Dhauladhar Range, Northwest Himalaya
}

\author{
${ }^{1}$ Wadia Institute of Himalayan Geology, 33 GMS Road, Dehradun 248001, Uttarakhand, India; ${ }^{+}$Email: thakurvc12@gmail.com \\ ${ }^{2}$ G. B. Pant National Institute of Himalayan Environment and Sustainable Development, Sikkim Regional Center, Pangthang, Gangtok \\ 737101, Sikkim, India;
}

(Received : 19/08/2018; Revised accepted : 23/05/2019)

https://doi.org/10.18814/epiiugs/2020/020020

A dynamic coupling between climate-induced erosion and tectonics is envisaged for the growth of the Himalaya. The Dhauladhar Range (NW Himalaya), between the Beas and Ravi rivers, shows large altitude variation along the regional trend from southeast to northwest. The altitude rises between $5000 \mathrm{~m}$ and $4000 \mathrm{~m}$ in the eastern part and decreases between $<4000 \mathrm{~m}$ and $2800 \mathrm{~m}$ in the western part. Eastern part of the Range is characterized with focused and highest precipitation, concentration of microseismicity and the formation of Kangra Basin to its south; whereas all these features are lacking in the western part. The Kangra Basin is a post-Siwalik intermontane basin between the Dhauladhar Range in the north and the Siwalik Range in the south. The basin-fill is essentially derived from the southern flank of the Dhauladhar Range as a consequence of erosion due to deglaciation. The Kangra Basin is developed as a piggy-back basin over the hanging wall of the foreland propagating Jawalamukhi Thrust (JT). The Optically Stimulated Luminescence (OSL) dating offluvial strath terrace surfaces, across the hanging wall, indicate late Quaternary reactivation of the JT. The Kangra Basin sediments yield late Quaternary OSL ages similar to that of the strath terraces. This suggests that formation of the Kangra Basin is synchronous with reactivation of the JT, implying a linkage among formation of the Kangra Basin, its filling through erosion of the Dhauladhar Range and reactivation of the Jawalamukhi Thrust.

\section{Introduction}

The Himalaya grew progressively through foreland-propagating thrust fault systems during Miocene to Pleistocene (Schelling and
Arita, 1991; Robinson et al., 2006). The principal thrust systems are the Main Central Thrust (MCT), the Main Boundary Thrust (MBT), and the Himalayan Frontal Thrust (HFT). Thickening of the crust in response to thrusting is considered largely responsible for the growth including uplift of the Himalaya (DeCelles et al., 2001; Yin, 2006; Robinson et al., 2006). It is now recognized that there is a feedback from climate and dynamic tectonic coupling in the growth of the Himalaya (Beaumont et al., 2001; Wobus et al., 2003; Thiede et al., 2004). The Dhauladhar Range (D-Range) of the Lesser Himalaya, trending NW-SE and lying between the Beas and Ravi Rivers, frames the northern margin of the Cenozoic foreland basin in the Kangra reentrant, Sub-Himalaya. The altitude at the water divide of the DRange decreases from $5000 \mathrm{~m}$ in the southeast to $2800 \mathrm{~m}$ in the northwest (Fig. 1A). The range can be divided along its regional trend into two parts, based on climate and elevation: the eastern part with altitude between 5000 and $4000 \mathrm{~m}$ and the western part with altitude between <4000 and $2800 \mathrm{~m}$. The intermontane Kangra Basin (KBasin) lies restricted to the south of the eastern part, whereas the basin does not extend to the western part with relative lower altitude. The structural and tectonic-stratigraphic framework is continuous and same along the D-Range. The question posed is what is genetic relationship between the JT and the K-Basin and what controls the aggradation of the $\mathrm{K}$-basin with respect to the Dhauladhar Range? The basin is occupied by the two large Kangra and Palampur fans (Fig. 1A). The loess deposits were reported for the first time by Sah and Srivastava (1992) from the alluvial fans of K-Basin. The pedogenesis of loess-paleosols in the fan sediments were studied in details and were dated through IRSL method. Based on these studies, the paleoclimatic episodes were deciphered during late Quaternary (Srivastava et al., 2009). More recently, climate-induced sediment aggradation and incision since Pleistocene has been deciphered within the $\mathrm{K}$-Basin through in situ cosmogenic ${ }^{10} \mathrm{Be}$ dating (Dey et al., 2016a). We have studied the K-Basin tectonics and carried out Optical Stimulated Luminescence (OSL) dating of the basin-fill of the Kangra fan sediments. South of the Kangra fan of the K-Basin, the Banganga (Baner) river incises the Siwalik strata and form large well-developed strath terraces, which were mapped by us overlying the Jawalamukhi Thrust (JT) and dated through OSL dating technique using sand-silt beds in the gravel cover (Thakur et al., 2014). The bedrock incision 


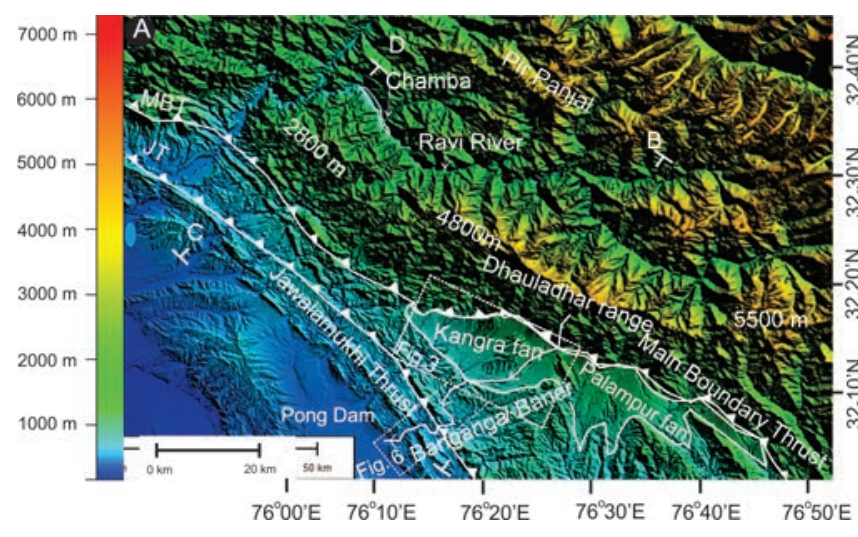

Figure 1. A) SRTM image shows physiographic-tectonic setting of the Dhauladhar-Kangra Basin. Altitude of Dhauladhar Range decreases, southeast to northwest, from 5000 to 2800 m. Kangra and Palampur fans constitute the K-Basin. The Kangra fan lies between the D-Range and the Siwalik Range. Insets: Location of Figs. 3 and 6. B) Cross-sections A-B and C-D indicated in Fig. 1A. a) Cross-section A-B across eastern part of the D-Range. b) Cross-section C-D across western part of the D-Range. Legend: 1-Indian crust, 2-Chamba sequence, 3-Dhauladhar granite, 4Salkhala/Haimanta Formation, 5-Panjal Imbricate Zone (Lesser Himalayan formations), 6-Dharamsala Formation, 7-Lower, Middle, Upper Siwaliks sequence, 8-Middle Siwalik Formation, 9-Late Quaternary Kangra Basin. Geology is after Thakur (1998).

(c) Cross-section, $x-y$, between the Jawalamukhi Thrust and the MBT, location shown in Fig. $2 B b$ (enlarged), extracted from the northern part of the balanced cross-section of Power et al. (1998). Legend: a-Pre Cambrian basement, b-Lower Dharamsala, c- Upper Dharamsala, d- Lower Siwalik, e- Middle Siwalik, f- Upper Siwalik, g- Late Quaternary sediment (thickness exaggerated).

of strath terraces implies uplift of the hanging wall of the JT, resulted due to slip over the fault in response to its reactivation. The geological setting of this basin on hanging wall of the JT and the OSL dates of geomorphic surfaces in the basin and strath terraces may suggest a climate-tectonic linkage between aggradation and incision.

\section{Geological Setting}

The Kangra Basin is a post-Siwalik intermontane basin, and lies on northernmost part of the Siwalik foreland basin in the Kangra reentrant (Fig. 2A). The basin is flanked to the north by the D-Range which rises abruptly from the Siwalik foreland (Fig. 1). The southern base of D-Range is demarcated by the closely-spaced Main Central Thrust (MCT) and the Main Boundary Thrust (MBT) (Fig. 1B) (Thakur, 1998). The D-Range is made of lower Paleozoic granite massif that extends in NW-SE direction along regional strike and emplaced as a concordant body within the Salkhala or Haimanta Formation. The Salkhala Formation, constituting the base of the Chamba nappe sequence, is thrust over the narrow belt of the Lesser Himalayan formations along the MCT, locally called as the Panjal Thrust (PT). The Lesser Himalayan belt is thrust over the Cenozoic Siwalik foreland basin along the MBT (Fig. 1B; Thakur, 1998). Reconstruction of exhumation history from the eroded detritus in the Kangra reentrant Siwalik strata reveals that the Salkhala Formation and the Lesser Himalaya sequences were exhumed to the surface by $\sim 17$ Ma and 9-6 Ma respectively (Najman et al., 2009). These age constraints imply the timing of the emergence of the MCT and MBT

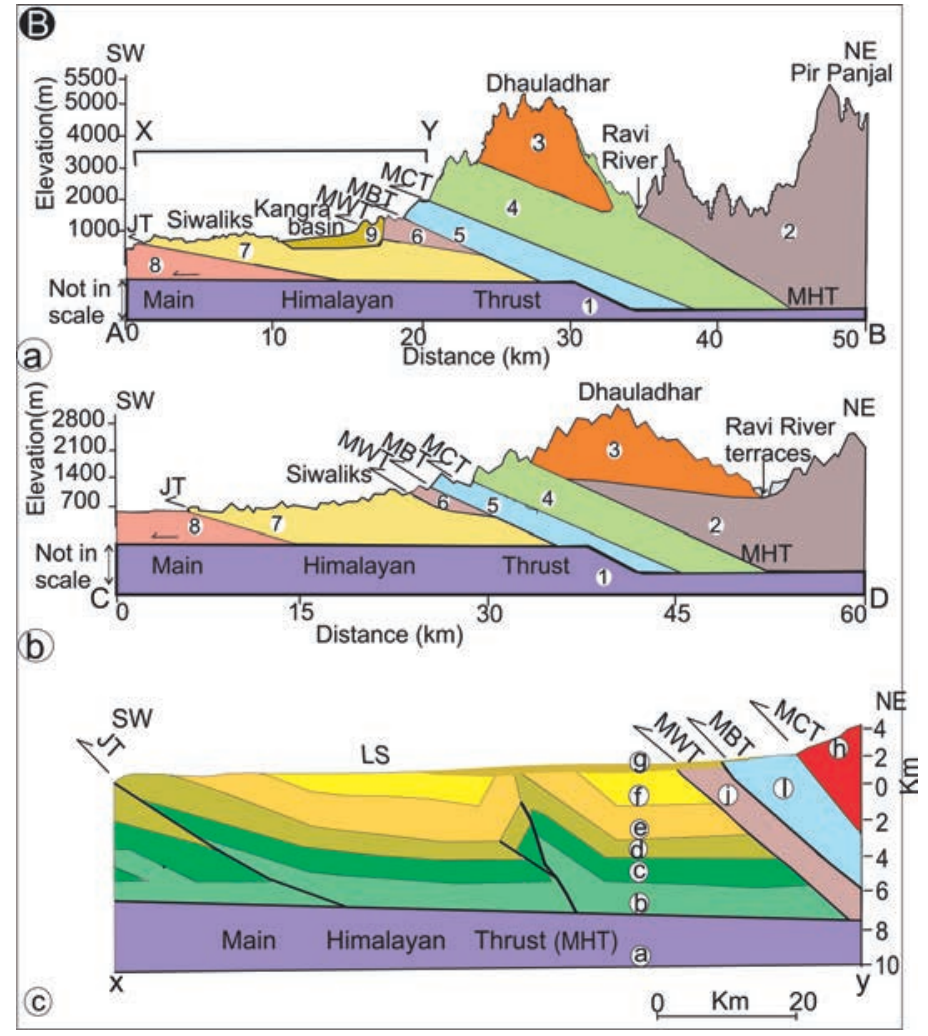

in the region. The principal thrusts, occurring along the southern base of the D-Range front (Fig. 1B), were drivers for its uplift. The AFT and ZHe dating across the transect from Dhauladhar, Pir Panjal and Higher Himalaya indicate about three times mean higher erosion rates over the frontal Dhauladhar Range in comparison to the hinterland ranges of the Pir Panjal and the Higher Himalaya (Deeken et al., 2011).

South of the D-Range, the foreland basin constitutes $\sim 80 \mathrm{~km}$ wide belt of foreland propagating fold-thrust system between the MBT and the Himalayan Frontal Thrust (HFT) (Karunakaran and Rao, 1979; Powers et al., 1998). South of the D-Range front and the MBT, the Paleocene-lower Eocene Subathu and Oligocene Dharamsala formations are thrust over the Neogene Siwaliks along the Palampur Thrust. Further south, the Middle and Upper Siwaliks constitute a partially eroded anticline, and to the north a broad and wide synform of the K-Basin. These are thrust over the Lower Siwalik along the Jawalmukhi Thrust (JT) (Figs. 2A, B). The seismic reflection profile across the Kangra re-entrant shows the JT branching off from the decollement (Powers et al., 1998), which is equivalent to the Main Himalayan Thrust (MHT).

\section{Geomorphic surfaces}

Three geomorphic surfaces are recognized within the Kangra fan in the K-Basin: a) Ridge top surface, b) Middle surface, and c) Lower surface (Fig. 3). There are isolated ridges trending NNE-SSW, separated by wide depressions filled in by the intervening fans of later generation. The distal part of the fan is characterized by relatively 

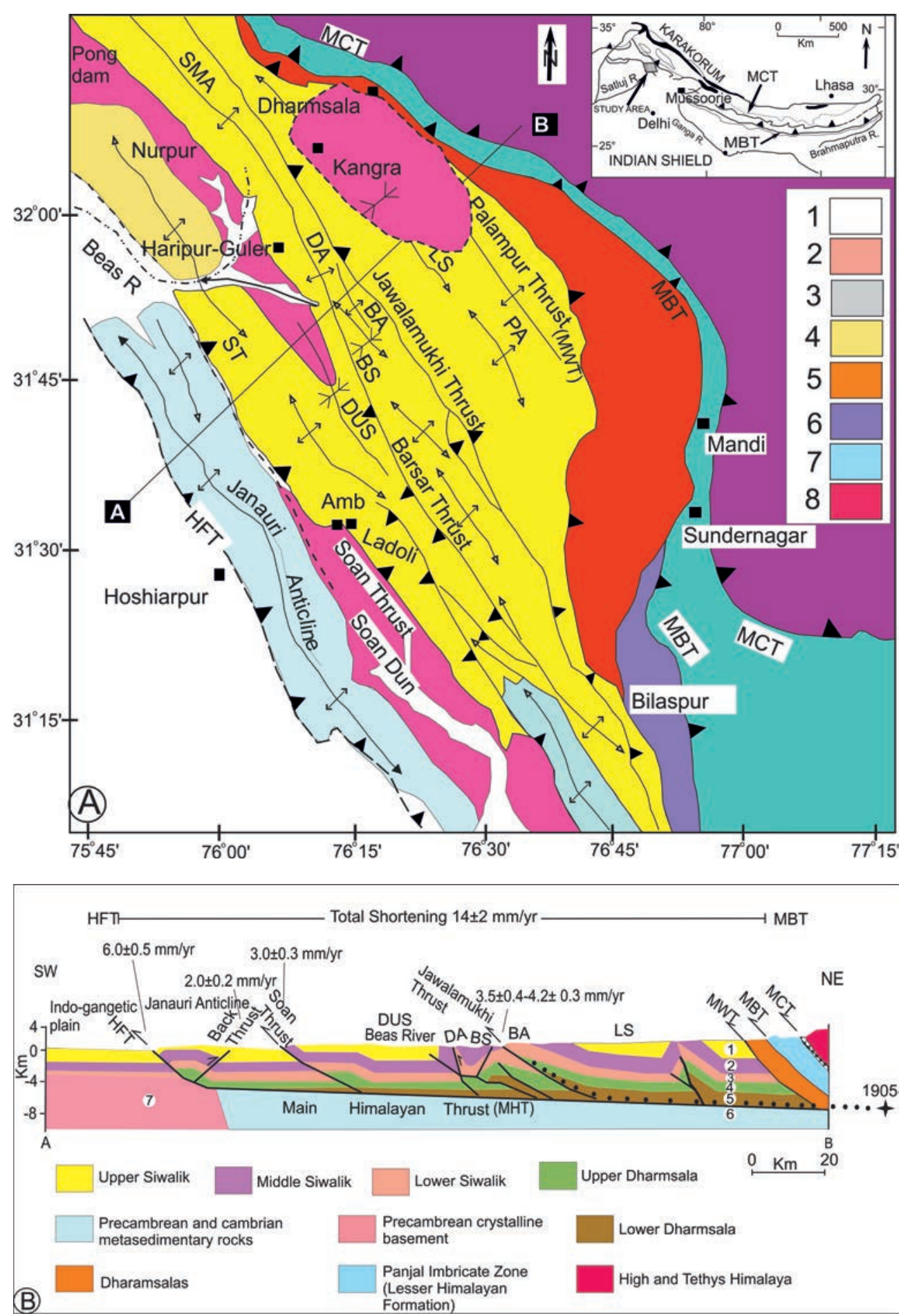

Figure 2. A) Regional geological map of Kangra re-entrant. MCT-Main Central Thrust, MBT-Main Boundary Thrust, PA-Paror Anticline, LS-Lambagaon Syncline, BA-Balh Anticline, BS-Balaru Syncline, DA-Dehra gopipur Anticline, DUS-Dumsa syncline, ST-Soan Thrust, HFT-Himalayan Frontal Thrust. Legend: 1-Alluvium, 2-Alluvial fan deposits in dun basins, 3-Frontal Siwalik Range (Upper, Middle Siwaliks) 4-Hinterland Siwaliks (Lower, Middle, Upper), 5-Dharamsalas, 6-Subathus, 7-PIZ: Panjal Imbricate Zone (Lesser Himalaya formations), 8-High and Tethys Himalayas. Map modified after Powers et al. (1998) and Thakur et al. (2014). B) Balanced cross-section across Kangra re-entrant based on A-B line in Fig. 1A, showing major structures, estimated shortening rates on the thrust faults. 1-Upper Siwalik, 2-Middle Siwalik, 3-Lower Siwalik, 4-Upper Dharamsala, 5-Lower Dharamsala, with thin Subathu, 6-Pre-Cambrian-Cambrian metasdimentaries (Vindhyan Group), 7-Pre-Cambrian Crystalline basement LS-Lambagaon Syncline, BA-Balh Anticline, BS-Balaru Syncline, DA-Dehragopipur Anticline, DUS-Dumsa syncline (after Powers et al., 1998). Shortening rates of thrusts taken from Thakur et al. (2014). planar surface of the Kangra valley that abuts against the Siwalik Range to the south.

\section{Ridge top surface}

The 900-1300 m elevated NNESSW trending isolated ridges, made of debris flow deposits, representing the highest geomorphic surface, are termed as the Ridge top surface (Fig. 3). The Dharamsala, Kuned, Naina Devi and Siund are the prominent ridges, representing the remnants of incised older fans. In places, where the incision is deep, the debris flow is underlain by consolidated Upper Siwalik Boulder Conglomerate at the base or with intervening unconsolidated boulder bed of fluvial origin. These are observed at the Baner river incising the Siund ridge, the Sarah stream incising the Dharamsala ridge, and the Nod incising the Kaned ridge. The ridges are composed of two types of lithologies: (a) granite debris flow consisting predominantly of cobbles and boulders of the Dhauladhar granite in sand matrix, dispersed with coarse white fresh feldspar laths and large to out-size granite boulders, $\geq 10$ $m$ across, occurring on the surface or within the debris flow, (b) mud flow debris of angular-subangular, poorly sorted pebble to boulder clast of sandstone, slate, quartzite and occasional granite in brownish matrix of silt and mud.

\section{Middle surface}

The areas between the raised ridges are occupied by the coalescing fans that extend from the mountain front to the distal part. The fans deposits are composed of clast to matrix-supported, unsorted to poorlysorted granite boulders with some phyllite and sandstone. Very large outsize (3-10 m diameter) granite boulders occur on the fan surface and along the channels of the southwest flowing streams, whereas medium- to small-size clasts are embedded in sand matrix with coarse grained quartz and fresh feldspar grains. The fans are largely debris flow deposits together with subordinate fluvial gravels along 
the stream channels and deposited in high energy condition. In the middle of the basin, the regional slope surface is uneven with average slope of $5^{\circ}$ to $10^{\circ}$ and covers the intervening areas between the ridges. The granite boulders-bearing debris flow extend right up to distal parts of the fans, and its deposits overlie uncomfortably the eroded consolidated Upper Siwalik Boulder Conglomerate at several places.

\section{Lower surface}

Nearly the flat valley surface of Kangra valley (basin) extends on both sides of the National Highway (NH-20) from near Shahpur through Gagal, Kangra, Nagrota and further east towards Paror and Paprola. The lower surface is flanked to the south by the Siwalik Range and merges to the north with the Middle surface and, at places, overlapped by the Ridge top surface (Fig. 3). Main part of the Kangra town is located on terminal part of the Lower surface, whereas the $17^{\text {th }}$ century Kangra Fort was built on the Siwalik Range that frames the southern margin of the Kangra fan. The Lower surface consists of subrounded, imbricated and stratified gravels and pebbles of quartzite and sandstone with some granite in sand-silt matrix. The clasts are matrix-supported with sand and mud beds. On the NH, at Chambi bridge in freshly-cut road, unconsolidated boulder-bearing gravel bed is exposed in a $30 \mathrm{~m}$ section, where it consists of subrounded to rounded clasts of purple and white colour quartzite with a few green volcanics in sand matrix or clasts-supported unit. This unit unconformably overlies the Upper Siwalik Boulder Conglomerate and, in turn, overlain with the granite boulder-bearing debris flow deposit. The clast composition and character of the boulder bed gravels suggest that these are largely derived from the Upper Siwalik Boulder Conglomerate.

\section{Kangra Basin}

The Kangra Basin (K-Basin) is developed within the northern part of the Siwalik foreland basin in the Kangra re-entrant. It has a unique tectonic-physiographic settings, as the basin lies south of the eastern Dhauladhar Range of the Lesser Himalaya that rises to 4000$5000 \mathrm{~m}$ (Figs. 1A, B). The K-Basin, occupying the Lambagaon syncline, lies over the hanging wall of the Jawalamukhi Thrust (JT), and has $\sim 15 \mathrm{~km}$ average width and $\sim 50 \mathrm{~km}$ lateral extent (Figs. 2A, $\mathrm{B})$. The provenance for the $\mathrm{K}-\mathrm{Basin}$ fill is essentially the sediments, derived from the D-Range, with porphyritic Dhauladhar granite as a marker lithology. In the proximal part, the fan sediments are dominantly cohesive debris and hyper-concentrated flows largely comprising of angular to subangular boulders and pebbles with outsize, 10-15 m diameter, boulders of the Dhauladhar granite. In the medial and distal parts, subordinate fluvial sediments including terraces are associated with the debris flows. Kangra, Rihlu and Palampur fans are described as coalescing alluvial fans (Sah and

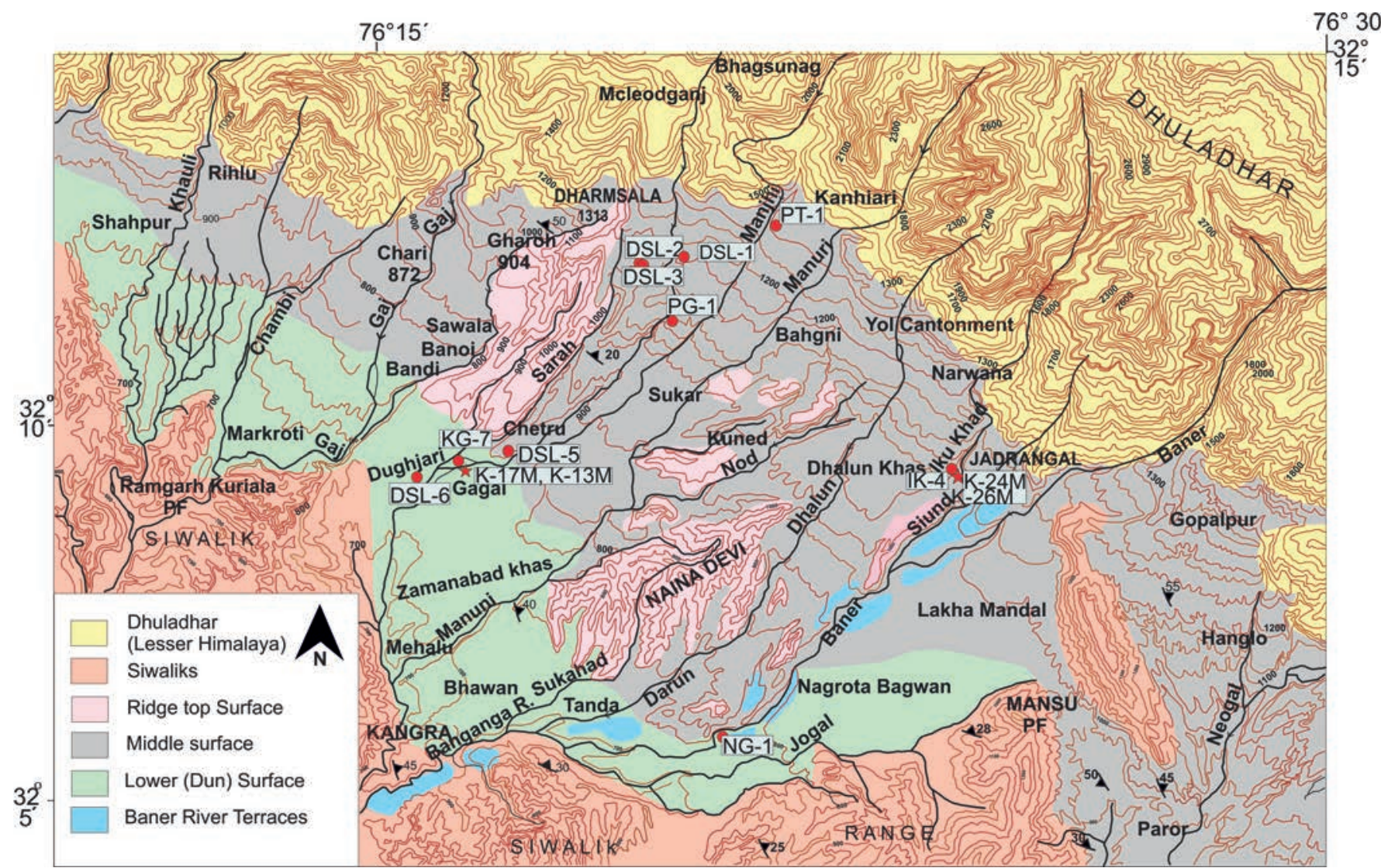

Figure 3. Geomorphologic map shows regional setting of the K-Basin, Kangra fan between the D-Range and the Siwalik Range and various surfaces present in the basin. The Ridge top surface (RTS) forms ridges trending NE-SW and the surface between the ridges is the Middle surface (MS). The Lower surface (LS) constitutes the near flat valley surface. Dip-strike symbol is the locality of Upper Siwalik Boulder Conglomerate underlying the debris flow exposed in incised sections. Red circle represents location of OSL and IRSL dated sample with their corresponding sample numbers. The geomorphologic map is based on 1:50,000 scale Survey of India toposheet. 
Srivastava, 1992; Srivastava et al., 2009), and are drained by feeder streams originating on the southern flank of the D-Range (Fig. 3). On the southern margin of the K-Basin, the Upper Siwalik Boulder Conglomerate formation dips NE $30^{\circ}$. In its northern extension, the Boulder Conglomerate formation continues underlying the K-Basin sediments with an intervening unconsolidated boulder bed, suggesting an unconformity. This stratigraphic unconformity is observed at several localities such as Gaj stream near Chambi, Churan stream south of Skoh, Mataur, Jheol along the NH, Baner stream section near Nagrota Bagwan and at the base of the Siund ridge (Fig. 3). Further in northernmost part of fans, the debris flow sediments unconformably overlie the Dharamsala Formation.

Based on the nature of clasts and matrix, we categorize three main types of the K-Basin fan sediments: a) Granite debris flow (Dfg): unsorted, angular to subangular, pebble to very large size granite boulders in coarse grit-sand-silt granitic matrix with fresh felspars laths. b) Mud flow debris (Dfd): angular to subangular unsorted clasts of largely Dharamsala sandstone with a few phyllite, quartzite, volcanics and rarely granite, embedded in brown earthy colour silt and mud matrix. At some places, the Dfd is overlain by the loessplaeosol. c) Boulder bed fluvial (Bbf): unconsolidated and partially stratified, with subrounded boulders to pebbles of sandstone, quartzite, phyllite and a few volcanics in sand matrix.

About 2-4 m thick loess beds occur as interbeds within the debris flow or form the top surface over the debris flow and fluvial sediments. Orange- to- brown colour loess paleosol horizons were identified as pedogenized loess through pedological analysis and dated at localities Iku khad in the proximal part and Gagal in the distal part of the Kangra fan (Srivastava et al., 2009). Loess-paleosol beds are observed at several other localities; notably around Police Ground and Post Office in the Dharamsala town, south of Yol Cantonment, Iku khad (stream), Gopalpur in the proximal part, along NH at Gagal airport and Dughiari in the distal part of the Kangra fan (Fig. 3).

Location of the $\mathrm{K}$-Basin adjacent to southern mountain front of the D-Range (Figs. 1A, 2A) and its drainage catchment indicates that the sediments for debris flow fans are dominantly derived from this range. In the proximal part of debris flow fans, angular and faceted boulders and cobbles of dominantly granite in coarse sand matrix with feldspar laths and also clasts-supported boulders occur near the exits of Churan, Manjhi, Manooni, Iku, and Baner streams. Some large outclasts granite boulders (size $>10 \mathrm{~m}$ ) occur as stand-alone erratics on debris flow surfaces. Large granite boulders, occurring as clusters on the fan surface and in stream channels, are distributed from proximal to distal parts of the fans (Fig. 4A). The outsize granite boulders stand-alone over the Lower surface in the terminal part of the fan (Fig. 4B), and also within the gravel cover of Baner river strath terrace at 800-600 m altitude. The outsize granite boulders are distributed in the Kangra fan and also reached up to 10-15 km away from the Range front in the distal part; size and distance travelled imply that these were either transported through catastrophic floods or through past glacial abrasion as is indicated by their striated and flat surfaces (Figs. 4C, 4D). Diamictite-type lithology having angular and unsorted clasts in sandy matrix, besides snow white sand matrix with undecomposed feldspar laths and grains, indicate their glacial origin and transport from the D-Range to the K-Basin during deglaciation. These glacier-related features, occurrence of loess paleosol beds within debris flows and physiographic setting of the basin suggest the debris flow fans similar to the paraglacial deposits

(Ryder, 1971a, b; Church and Ryder, 1972).

\section{Optically Stimulated Luminescence (OSL) Chronology}

Loess-paleosol bands occurring within the Kangra fan sediments were earlier dated using Infrared Stimulated Luminesence (IRSL) method in the proximal and distal parts of the fan (Srivastava et al., 2009). We produced additional OSL dates from other parts of the Kangra fan, and also incorporated earlier published OSL dates of the strath terraces along the Baner River (Thakur et al., 2014). The OSL dating was carried at the Wadia Institute of Himalayan Geology, Dehra Dun, following the standard protocol (Murray and Wintle, 2000). Table 1 presents the IRSL and OSL dates of sediments of the Kangra Basin from its proximal and distal parts of the fan and strath terraces south of Kangra along with recently-published ${ }^{10}$ Be dates (cf., Dey et al., 2016a, b).

\section{Proximal part of Kangra fan}

The sand sample (DSL 2), extracted from the Dfg unit in a trench near the main Petrol pump of Dharamsala (32²' $12^{\circ} 19^{\prime}$ ) (Fig. 5a), gives OSL age as $30.3 \pm 5.2 \mathrm{ka}$ (Table 1 ). The Dfg extends to the south along the ridge top surface, and a second sample (DSL 3), extracted $\sim 5 \mathrm{~km}$ south of the Petrol pump ( $32^{\circ} 11^{\prime}: 76^{\circ} 17^{\prime}$ ), gives OSL age of $40.5 \pm 5.3 \mathrm{ka}$ (Table 1) (Fig. 5b). In the proximal part of the Kangra fan near mountain front, $\sim 8 \mathrm{~km}$ east of Dharamsala at Patola Khanyara (32 $\left.12^{\prime}: 76^{\circ} 21^{\prime}\right)$, a sand lens (PAT-1) gives OSL age of $12.5 \pm 1.1 \mathrm{ka}$ in the debris flow (Fig. 5c) (Table 1).

The Dfd lithological unit is best exposed on the eastern margin of Dharamsala ridge. It consists of subangular, unsorted, cobbles to pebbles size clasts in silt-mud matrix. The clasts are largely ( 90\%) of sandstone, quartzite and a few phyllite and rarely granite. The Dfd top is characterized with 2-3 m thick orange yellow loess-paleosols as exposed near Police Ground and Post Office slope of Dharamsala town. Further south towards the terminal part of the Dharamsala ridge, the Dfd merges with the distal planar lower surface near Gagal Airport, where orange to brown-red loess paleosols are exposed. On the eastern margin of the Dhrarmsala ridge, the mud flow deposit (DSL1) gives OSL ages of $7.5 \pm 0.5 \mathrm{ka}$ (Table 1 ) near Lajwanti nursery, Shyamnagar ( $\left.32^{\circ} 12^{\prime}: 76^{\circ} 19^{\prime}\right)$ and $7.6 \pm 0.5 \mathrm{ka}$ (PG 1, Table 1 ) near the base of cliff section close to cricket stadium (32 $\left.{ }^{\circ}, 76^{\circ} 20^{\prime}\right)$. These two younger Holocene ages may be due to reworking and redeposition of the older fan sediment.

In the proximal part of the fan, northward continuation of the Siund ridge, the Iku khad section exposes $4 \mathrm{~m}$ thick loess-paleosol bed overlain and underlain by the granite boulder-bearing debris flow. The IRSL ages of the loess paleosol of the Iku Khad section are 78.6 $\pm 17.7 \mathrm{ka}$ (K26 M, Table 1) at the base and 44.2 $\pm 6.2 \mathrm{ka}$ (K24 M, Table 1) for the top (Srivastava et al., 2009). We dated the sand bed in debris flow overlying the loess-plaleosol at road section along Iku stream, which yields OSL age as $24.1 \pm 3.1 \mathrm{ka}$ (Table 1).

\section{Distal part of Kangra fan}

The unconsolidated boulder bed exposed at Chambi bridge extends eastward along the $\mathrm{NH}$, at the road bend towards Gagal Airport, is overlain by debris flow and capped by $3 \mathrm{~m}$ thick orangered loess paleosol. A sand band in unconsolidated boulder bed gives OSL age as $91.0 \pm 13.9$ ka (KG 7, Table 1 ). The orange red loess- 

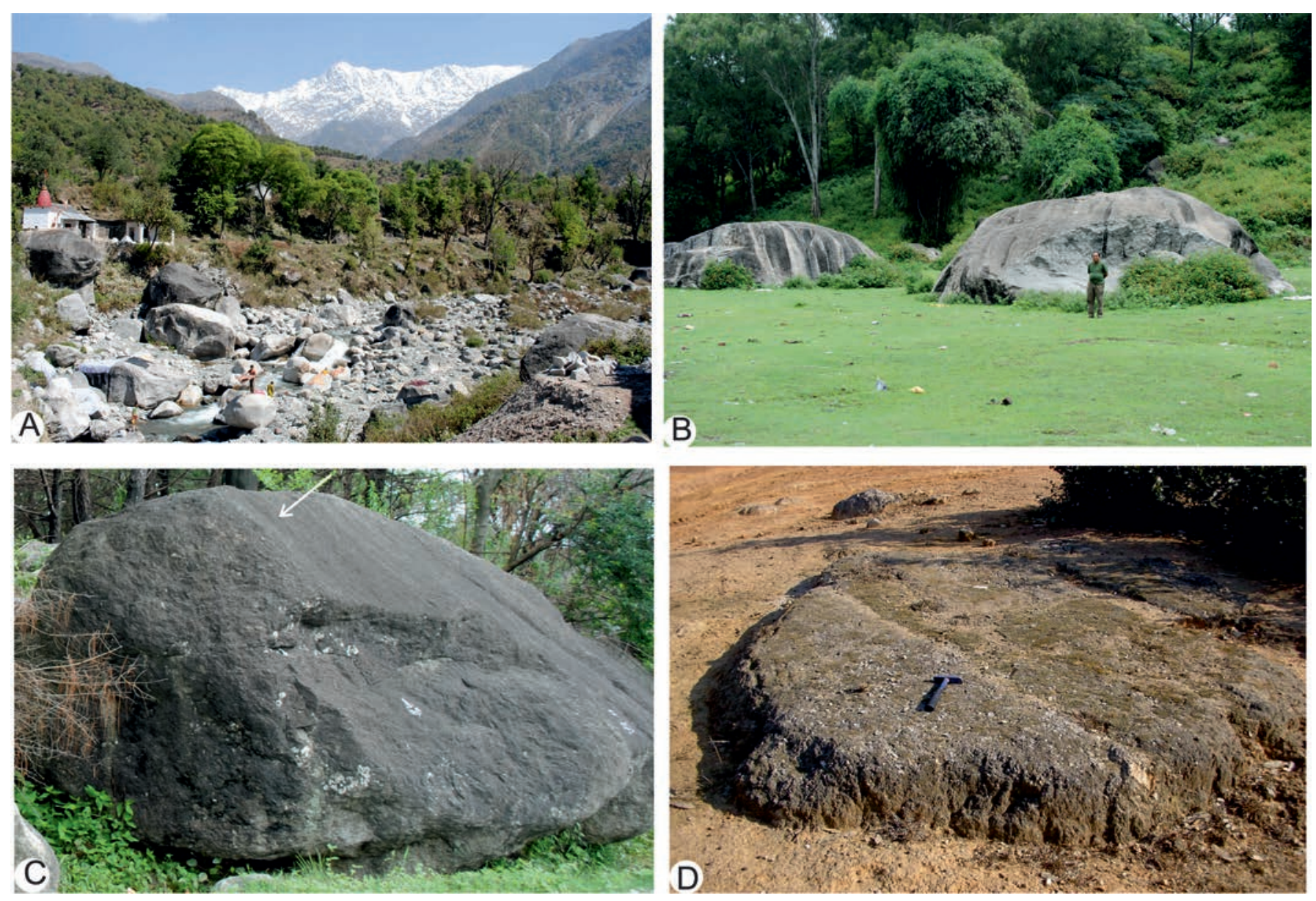

Figure 4. A). Outsize granite boulders (scale: a man standing on boulder) in the Manjhi river channel consisting debris flow deposit. B) Out-size granite boulder is in the distal part, lower surface, $15 \mathrm{~km}$ south of the mountain front. C) Glacial striations on the granite boulder. D) Granite boulder abraded with flat surface. Boulder is embedded in silt-clay matrix, D-Range-red loess paleosol.

paleosol bed extends along the highway close to entrance of Gagal Airport. This unit is correlatable to the Gagal loess paleosol, reported and dated by Srivastava et al. (2009). The unit gives IRSL ages as $30.8 \pm 7.7 \mathrm{ka}(\mathrm{K} 17 \mathrm{M}$, Table 1$)$ for the bottom part and $19.9 \pm 3.5 \mathrm{ka}$ (K13 M, Table 1) for the top part. At a locality, along the road cutting between Tiara and Dughiari, $3 \mathrm{~m}$ thick orange-red loess paleosol unit gives OSL age as $40.7 \pm 2.5 \mathrm{ka}$ (DSL 6, Table 1 ). This locality a few $\mathrm{km}$ to the south represents the extension of the loess paleosol exposed along the highway close to Gagal Airport. Further north, the sand lens in granite boulder-bearing debris flow overlying the loess paleosol is dated as $15.1 \pm 1.6 \mathrm{ka}$ (DSL 5, Table 1). West of Nagrota Bagwan along the Baner River bridge, 20 km east of Gagal, the lower surface constitutes the Upper Siwalik Boulder Conglomerate, overlain by unconsolidated boulder bed. The boulder bed consists of clasts of granite with some quartzite and sandstone clasts in sand and grit matrix. Here, the sand lens in the unconsolidated boulder bed gives OSL age as $18.3 \pm 0.5 \mathrm{ka}$ (NG 1, Table 1$)$.

\section{Strath terraces in Siwalik bed rock}

The K-Basin is flanked to the south by the Siwalik Range, where strath terraces are developed along the Baner River. It flows southwest from the southern slope of the Dhauladhar Range and drains into the Pong dam reservoir erected across the Beas river (Fig. 1A). The river incises the Kangra fan sediments in northern part and the Siwalik Range strata in southern part. This river incises $40-88 \mathrm{~m}$ of the Siwalik bedrock, and deposits 5-20 m thick fluvial gravel cover with welldeveloped gravel strath terraces having subrounded to rounded boulders of Dhauladhar granite together with sandstone-siltstone, phyllite and quartzite. The strath (bedrock) terraces were mapped and dated using OSL technique along the Baner (Banganga) river (Fig. 6) (Thakur et al., 2014). Kangra $\mathrm{T}_{3}, \mathrm{~T}_{2}$, Chatra $\mathrm{T}_{3}$, Jaladi $\mathrm{T}_{4}$, Jalakhadi $\mathrm{T}_{2}$ and Haripur $\mathrm{T}_{2}$ terraces are located $65 \mathrm{~m}, 49 \mathrm{~m}, 75 \mathrm{~m}, 88$ $\mathrm{m}, 70 \mathrm{~m}$ and $40 \mathrm{~m}$ above the river grade, respectively. The strath terrace surfaces are overlain with 5-10 m thick gravel cover in sand/ silt matrix. The sand layer in gravels over strath surfaces were OSLdated to determine their abandoned ages and time of incision. The strath terrace surfaces give OSL ages as: a) $18.3 \pm 2.6$ ka (Kangra $\mathrm{T}_{2}$ ) and $33.6 \pm 3.7 \mathrm{ka}\left(\right.$ Kangra $\left.\mathrm{T}_{3}\right)$, b) $30.7 \pm 1.2 \mathrm{ka}\left(\right.$ Chatra $\left.\mathrm{T}_{3}\right)$, c) $76.2 \pm$ $8.6 \mathrm{ka}$ (Jaladi $\mathrm{T}_{4}$ ), d) $22.8 \pm 2.7 \mathrm{ka}$ (Jalakhadi $\mathrm{T}_{2}$ ), and e) $13.0 \pm 1.5 \mathrm{ka}$ (Haripur $\mathrm{T}_{2}$ ) (Table 1). Based on vertical offset (distance between river grade and strath surface), OSl date and $30^{\circ}$ dip of JT, uplift and shortening rates are estimated (Fig. 2B). The bed-rock incision (uplift) rates estimated for the $\mathrm{T}_{3}$ and $\mathrm{T}_{2}$ terraces are $2.0-2.4 \mathrm{~mm} / \mathrm{yr}$ and $2.8-$ $3.1 \mathrm{~mm} / \mathrm{yr}$ over a period 33-30 ka and 22-18 ka, respectively. The bed-rock incision of the strath terraces is considered as representing bed-rock uplift. The strath terraces, lying over the hanging wall of the Jawalmukhi Thrust (JT), were uplifted as a result of slip-induced 
Table 1. Compiled dates of Kangra basin sediments and Baner (Banganga) River strath terraces.

Kangra Basin (Present study)

\begin{tabular}{|c|c|c|c|c|c|c|c|c|c|c|}
\hline \multirow{2}{*}{$\begin{array}{l}\text { Sample } \\
\text { No. }\end{array}$} & \multirow[t]{2}{*}{ Location } & \multirow{2}{*}{$\begin{array}{c}\text { Sample } \\
\text { depth } \\
\text { (m) }\end{array}$} & \multirow[b]{2}{*}{$\mathrm{U}(\mathrm{ppm})$} & \multirow[b]{2}{*}{ Th (ppm) } & \multirow[b]{2}{*}{$\begin{array}{c}\text { Potassium } \\
\text { K (\%) }\end{array}$} & \multicolumn{2}{|c|}{ Equivalent Dose (De) Gy } & \multirow[b]{2}{*}{$\begin{array}{c}\text { Dose rate } \\
(\mathrm{Gy} / \mathrm{ka})\end{array}$} & \multicolumn{2}{|c|}{ Age (ka) } \\
\hline & & & & & & $\begin{array}{l}\text { Weighted } \\
\text { Mean De }\end{array}$ & Mean De & & $\begin{array}{c}\text { Weighted } \\
\text { Mean }\end{array}$ & Mean \\
\hline DSL-1 & $32^{\circ} 12^{\prime} / 76^{\circ} 19^{\prime}$ & 2 & $3.1 \pm 0.03$ & $18.5 \pm 0.19$ & $1.69 \pm 0.02$ & $26.65 \pm 1.67$ & $26.90 \pm 1.72$ & $3.57 \pm 0.05$ & $7.5 \pm 0.5$ & $7.5 \pm 0.5$ \\
\hline DSL-2 & $32^{\circ} 12^{\prime} / 76^{\circ} 19^{\prime}$ & 2 & $4.2 \pm 0.04$ & $25.1 \pm 0.25$ & $3.85 \pm 0.04$ & $188.3 \pm 32.24$ & $204.86 \pm 30.07$ & $6.21 \pm 0.08$ & $30.3 \pm 5.2$ & $33.0 \pm 4.9$ \\
\hline DSL-3 & $32^{\circ} 11^{\prime} / 76^{\circ} 17^{\prime}$ & 2 & $4.8 \pm 0.05$ & $35.4 \pm 0.35$ & $3.49 \pm 0.03$ & $270.11 \pm 34.90$ & $269.69 \pm 33.59$ & $6.67 \pm 0.09$ & $40.5 \pm 5.3$ & $40.5 \pm 5.1$ \\
\hline DSL-5 & $32^{\circ} 10^{\prime} / 76^{\circ} 15^{\prime}$ & 2 & $4.6 \pm 0.05$ & $32.7 \pm 0.33$ & $3.78 \pm 0.04$ & $101.33 \pm 10.63$ & $103.41 \pm 8.90$ & $6.70 \pm 0.09$ & $15.1 \pm 1.6$ & $15.4 \pm 1.3$ \\
\hline DSL-6 & $32^{\circ} 08^{\prime} / 76^{\circ} 14^{\prime}$ & 2 & $2.2 \pm 0.02$ & $21.3 \pm 0.21$ & $2.19 \pm 0.02$ & $163 \pm 9.8$ & $163.74 \pm 9.06$ & $4.01 \pm 0.05$ & $40.7 \pm 2.5$ & $40.9 \pm 2.3$ \\
\hline PAT-1 & $32^{\circ} 12^{\prime} / 76^{\circ} 21^{\prime}$ & 3 & $3.65 \pm 0.04$ & $20 \pm 0.2$ & $2.24 \pm 0.02$ & $51.87 \pm 4.7$ & $55.55 \pm 5.60$ & $4.16 \pm 0.06$ & $12.5 \pm 1.1$ & $13.3 \pm 1.4$ \\
\hline NG-1 & $32^{\circ} 05^{\prime} / 76^{\circ} 22^{\prime}$ & 18 & $4.86 \pm 0.05$ & $19.7 \pm 0.2$ & $2.41 \pm 0.02$ & $78.23 \pm 1.95$ & $78.57 \pm 1.98$ & $4.29 \pm 0.07$ & $18.3 \pm 0.5$ & $18.3 \pm 0.6$ \\
\hline PG-1 & $32^{\circ} 5^{\prime} / 76^{\circ} 20^{\prime}$ & 50 & $2.2 \pm 0.02$ & $14 \pm 0.14$ & $1.76 \pm 0.02$ & $23.88 \pm 1.68$ & $24.12 \pm 1.76$ & $3.13 \pm 0.04$ & $7.6 \pm 0.5$ & $7.7 \pm 0.6$ \\
\hline IK-4 & $32^{\circ} 09^{\prime} / 76^{\circ} 24^{\prime}$ & 4 & $1 \pm 0.01$ & $20.1 \pm 0.2$ & $4.0 \pm 0.04$ & $133.49 \pm 17.29$ & $154.31 \pm 36.4$ & $5.54 \pm 0.07$ & $24.1 \pm 3.1$ & $27.9 \pm 6.6$ \\
\hline KG-7 & $32^{\circ} 10^{\prime} / 76^{\circ} 15^{\prime}$ & 6 & $1.72 \pm 0.02$ & $16.6 \pm 0.17$ & $2.64 \pm 0.03$ & $376.21 \pm 57.2$ & $428.91 \pm 53.72$ & $4.14 \pm 0.05$ & $91.0 \pm 13.9$ & $103.7 \pm 13.1$ \\
\hline
\end{tabular}

Srivastava et al. (2009)

\begin{tabular}{|c|c|c|c|c|c|c|c|c|}
\hline Sample no. & Location & Depth & ${ }^{238} \mathrm{U}$ (ppm) & ${ }^{232} \mathrm{Th}$ (ppm) & ${ }^{40} \mathrm{~K}(\%)$ & Dose rate & (Gy/ka) ED & (Gy) Age (ka) \\
\hline $\mathrm{K}-13 \mathrm{M}$ & Gagal-II, & $3 \mathrm{~m}$ & $4.9 \pm 2.20$ & $16.50 \pm 4.00$ & 2.3 & $6.00 \pm 1.00$ & $119.8 \pm 8.1$ & $19.9 \pm 3.5$ \\
\hline $\mathrm{K}-17 \mathrm{M}$ & Gagal-II, & $5.5 \mathrm{~m}$ & $4.7 \pm 2.2$ & $15.8 \pm 3.8$ & 2.9 & $5.7 \pm 1.0$ & $177.5 \pm 32.1$ & $30.8 \pm 7.7$ \\
\hline $\mathrm{K}-24 \mathrm{M}$ & Iku, & $16 \mathrm{~m}$ & $8.9 \pm 3.0$ & $29.6 \pm 5.4$ & 2.4 & $9.0 \pm 1.4$ & $398.5 \pm 36.9$ & $44.2 \pm 6.2$ \\
\hline $\mathrm{K}-26 \mathrm{M}$ & Iku, & $18 \mathrm{~m}$ & $12.3 \pm 3.5$ & $41.0 \pm 6.4$ & 2.2 & $11.5 \pm 1.7$ & $901.66 \pm 151.2$ & $78.6 \pm 17.7$ \\
\hline
\end{tabular}

Dey et al. (2016a)

\begin{tabular}{lcccc}
\hline Sample no. & Location & $\begin{array}{c}\text { Exposure age (St age) (depth } \\
\text { profile)(ka) }(2 \sigma \text { error) }\end{array}$ & $\begin{array}{c}\text { Exposure age (Lm age) (depth } \\
\text { profile fit) (ka) }(1 \sigma \text { error) }\end{array}$ & $\begin{array}{c}\text { Exposure age (Lm age) (inheritance- } \\
\text { corrected surface sample) }(\mathrm{ka})(1 \sigma \text { error) }\end{array}$ \\
\hline T1-P1 (sc. B) & $32.068 / 76.399$ & $57.3 \pm 4.5$ & $53.4 \pm 3.2$ & $48.7 \pm 3.1$ \\
T1-P2 & $32.059 / 76.426$ & $50.1 \pm 4.1$ & $43.0 \pm 2.7$ & $39.2 \pm 2.8$ \\
T2-P2 & $32.184 / 76.297$ & $19.5 \pm 2.2$ & $18.6 \pm 1.2$ & $19.8 \pm 1.3$ \\
T2-P1 & $32.106 / 76.262$ & $16.3 \pm 1$ & $15.3 \pm 0.9$ & $16.1 \pm 1.0$ \\
\hline
\end{tabular}

Banganga (Baner) river strath terraces (Thakur et al., 2014)

\begin{tabular}{|c|c|c|c|c|c|c|c|c|c|c|}
\hline \multirow[b]{2}{*}{$\begin{array}{l}\text { Sample } \\
\text { No. }\end{array}$} & \multirow[b]{2}{*}{ Location } & \multirow{2}{*}{$\begin{array}{c}\text { Sample } \\
\text { depth } \\
\text { (m) }\end{array}$} & \multirow[b]{2}{*}{$\mathrm{U}(\mathrm{ppm})$} & \multirow[b]{2}{*}{ Th (ppm) } & \multirow[b]{2}{*}{$\begin{array}{c}\text { Potassium } \\
\text { K (\%) }\end{array}$} & \multicolumn{2}{|c|}{ Equivalent Dose (De) Gy } & \multirow[b]{2}{*}{$\begin{array}{c}\text { Dose rate } \\
\text { (Gy/ka) }\end{array}$} & \multicolumn{2}{|c|}{ Age (ka) } \\
\hline & & & & & & $\begin{array}{l}\text { Weighted } \\
\text { Mean De }\end{array}$ & Mean De & & $\begin{array}{l}\text { Weighted } \\
\text { Mean }\end{array}$ & Mean \\
\hline DSL-8 & $32^{\circ} 052 / 76^{\circ} 162$ & 3 & $3.95 \pm 0.04$ & $22.85 \pm 0.23$ & $2.5 \pm 0.03$ & $89.46 \pm 12.59$ & $93.92 \pm 20.14$ & $4.9 \pm 0.06$ & $18.3 \pm 2.6$ & $19.2 \pm 4.2$ \\
\hline JL-1 & $32^{\circ} 03^{\prime} / 76^{\circ} 13^{\prime}$ & 5 & $3.23 \pm 0.03$ & $14 \pm 0.14$ & $2 \pm 0.02$ & $279.69 \pm 31.52$ & $294.69 \pm 35.7$ & $3.67 \pm 0.04$ & $76.2 \pm 8.6$ & $80.3 \pm 9.8$ \\
\hline RN-1 & $32^{\circ} 012 / 76^{\circ} 132$ & 4 & $1.25 \pm 0.01$ & $15 \pm 0.15$ & $2.61 \pm 0.03$ & $86.37 \pm 10.34$ & $87.99 \pm 9.41$ & $3.78 \pm 0.26$ & $22.8 \pm 2.7$ & $23.3 \pm 3.0$ \\
\hline RN-2 & $32^{\circ} 012 / 76^{\circ} 142$ & 3 & $2.01 \pm 0.01$ & $24 \pm 0.24$ & $4.12 \pm 0.04$ & $188.21 \pm 6.80$ & $188.85 \pm 6.70$ & $6.13 \pm 0.07$ & $30.7 \pm 1.2$ & $30.8 \pm 1.1$ \\
\hline
\end{tabular}

upthrust motion. The JT is characterized by a fault-propagated frontal anticline (eroded) and a complementary broad synform of the KBasin, mapped as Lambagaon syncline (Karunakaran and Rao, 1979; Powers et al., 1998). The tectonic setting of the K-Basin is analogous to that of the piggy-back basin, formed and were filled while being carried on the moving thrust sheet (Ori and Friend, 1984).

\section{Deglaciation induced erosion}

The southern flank of eastern D-Range and adjoining mountain spurs were the provenance for the K-Basin. In northwest Himalaya, the Pir Panjal and Dhauladhar Ranges, the Beas valley, the Lahaul and Garhwal regions are affected by the same climate system. These regions receive South Asian summer monsoon during summer and mid-latitude westerlies during the winters. In the upper Beas valley south of Rohtang pass, an area close to the D-Range and $80 \mathrm{~km}$ east of Dharamsala, the morains are reported from the Solang and Palchan valleys at the lowest altitude of 2500 m (Owen et al., 1996, 1997). In the Ravi river catchment of the Chamba area, on northern flank of the D-Range, the glaciation features are reported at altitude as low as 2600 m (Joshi and Tandon, 1987; Joshi, 2014). In the higher altitude of eastern segment of the D-Range glaciers, glacial lakes and glacialcarved physiographic features are observed in the Google images. In the Survey of India topographic maps on 1:50, 000 scale, there are 12 falls (water) indicated with 40-60 m height scarps at altitude ranging $3500 \mathrm{~m}$ to $3000 \mathrm{~m}$. At Bhagsu Nath near Mcleodganj, there is a moraine ridge of $\sim 500 \mathrm{~m}$ long and $\sim 50 \mathrm{~m}$ high, consisting of large, angular and unsorted granite boulders in sand-grit matrix, granite 

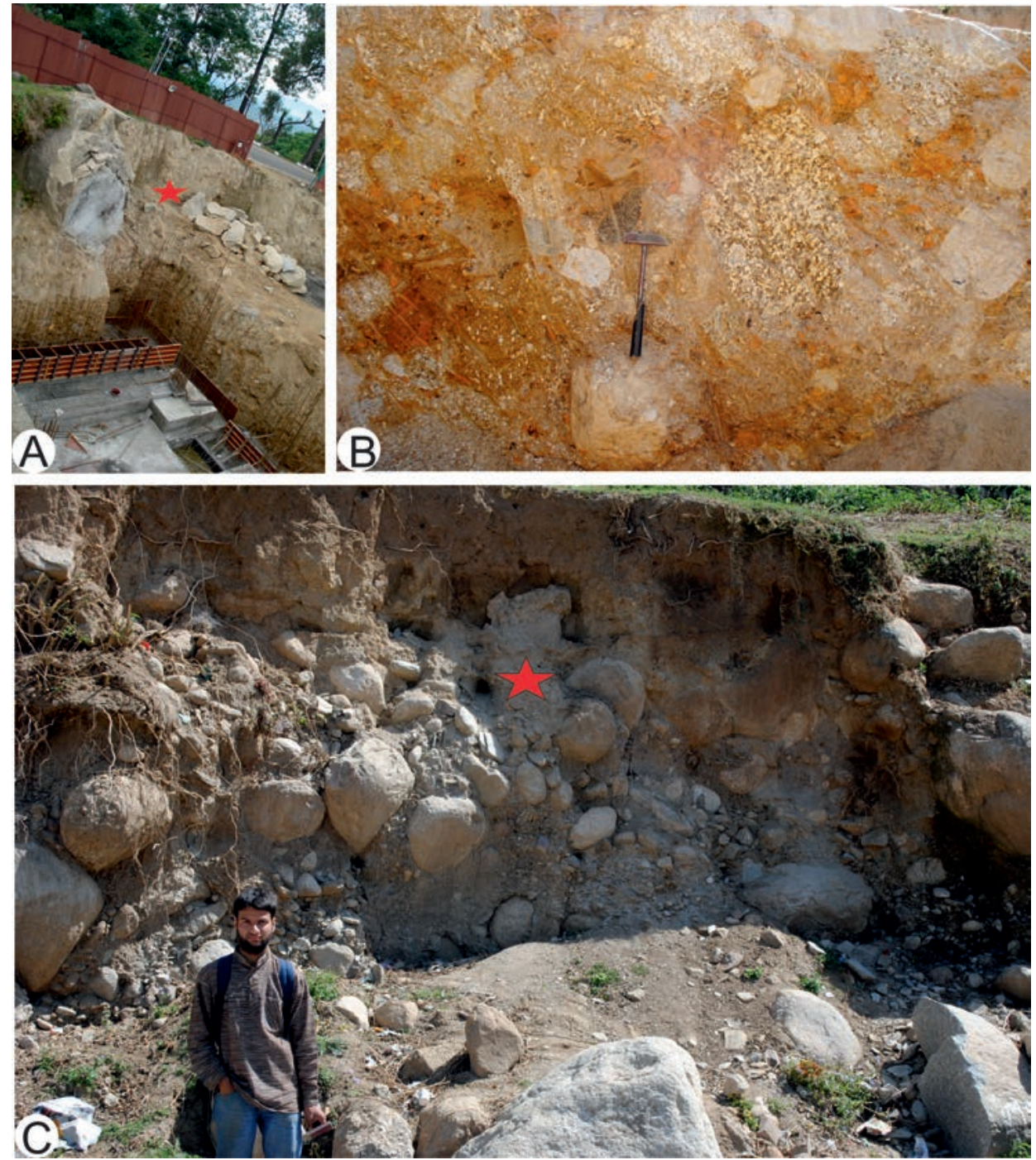

Figure 5. Localities of OSL dated samples. A) A trench adjacent petrol pump near Kotwali bazaar Dharamsala (32 $\left.{ }^{\circ} 2^{\prime}: 76^{\circ} 19^{\prime}\right)$, sample: (DSL 2). B) Near Kunal Patri temple, Dharamsala ridge (32 $\left.{ }^{\circ} 11^{\prime}: 7^{\circ} 17^{\prime}\right)$, sample: (DSL3). C) Patola, Ghanyara, $8 \mathrm{~km}$ east of Dharamsala (32 $10^{\circ}: 7^{\circ} 15^{\prime}$ ), sample: (DSL 5).

erratics and a waterfall along the Churan stream. Similar features of the past glaciation also occur near the exits of Manjhi and Manuni streams (Fig. 3), and indicate that the glacier margin lobes extended down to lower altitude.

The eastern D-Range is characterized with high altitude of 5000$4000 \mathrm{~m}$ and steep gradient, which receives focused southwest monsoon precipitation up to 2500-3000 mm/yr (Sharma and Bandooni, 2007). The glaciers are highly efficient erosional agents, more effective than fluvial erosion, and produce large volumes of debris sediments within their restricted domains (Hallet et al., 1996). During the glaciation period, the glacier cover and their downward advances on the steeper gradients produce large volume of debris through glacial denudational processes. Glacially-eroded sediment flux was later transported during monsoon precipitation or by catastrophic floods and deposited in the K-Basin. The occurrence of loess deposits in the fan sediments indicates cold-arid climate. In the mountainous areas, the loesses are deposited on the margins of glaciers. We obtained $40 \mathrm{ka}$ OSL age from near the top surface of the loess-paleosol in the distal part of the fan near Dughiari, and 30-40 ka ages from the unit Dfg at the proximal part of the fan along Dharamsala ridge. These OSL ages are nearly analogous to the OSL dates 43-36 ka obtained for Batal glacial stage-I reported in the neighbouring Lahaul area (Owen et al., 1997). Srivastava et al. (2009) advocated glacial advances in the area at 78-44 ka and 30-20 ka during the last glacial cycle. In more recent study, the Kangra fan sediments are dated using cosmogenic nuclide $\left({ }^{10} \mathrm{Be}\right)$ dating method. The two sets of ages obtained are $53.4 \pm 3.2 \mathrm{ka}$ and $43.0 \pm 2.2 \mathrm{ka}$ for the older fan and $18.6 \pm 1.2 \mathrm{ka}$ and $15.3 \pm 0.9 \mathrm{ka}$ for the younger fan (Dey et al., 2016a). The OSL ages and climatic signatures in the Kangra fan sediments suggest more extensive last glacial cycle as compared to the LGM affecting the Dhauladhar Range. This period coincides with the period of insolation maximum and strengthening of monsoon and advance of glaciers (Owen et al., 2002).

\section{Discussions and conclusions}

The K-Basin fan sediments were deposited in a growing synformal depression of the Lambagaon syncline (Figs. 2A, B), similar to the dun, created between the MBT and the JT. The Upper Siwalik Boulder Conglomerate, constituting the base of the K-Basin sediments, represents continuation of the Boulder Conglomerate that forms upper part of the sequence exposed in KangraRanital section. The magnetostratigraphic dating of this section gives 5.9 Ma age at the base (Sangode et al., 2003), whereas 0.2 Ma age is assigned to the top part of the Boulder Conglomerate in Jammu area (Rao et al., 1988). The Boulder Conglomerate is consolidated with sand-grit matrix and composed of pebbles, cobbles and boulders of predominantly quartzite, sandstone and siltstone with some volcanics and phyllite of the Lesser Himalayan affinity with a few granitic gneiss and leucogranite of the Higher Himalaya Crystalline affinity. The clast composition indicates their provenance largely from the Lesser Himalaya and to some extent from the Higher Himalaya. Lack of Dhauladhar granite clasts in the Upper Siwalik Boulder Conglomerate and their predominance in the fans of K-Basin imply that the D-Range granite was not the prime source for the Boulder Conglomerate, whereas the same granite body contributed significantly to the K-Basin. This may imply that exhumation of the Dhauladhar granite occurred post-Upper Siwalik Boulder Conglomerate to become the source for the K-Basin. This may further suggest that southwesterly-flowing rivers/streams, originating from the southern flank of D-Range, were developed during the renewed uplift of the D-Range post-dating the Upper 


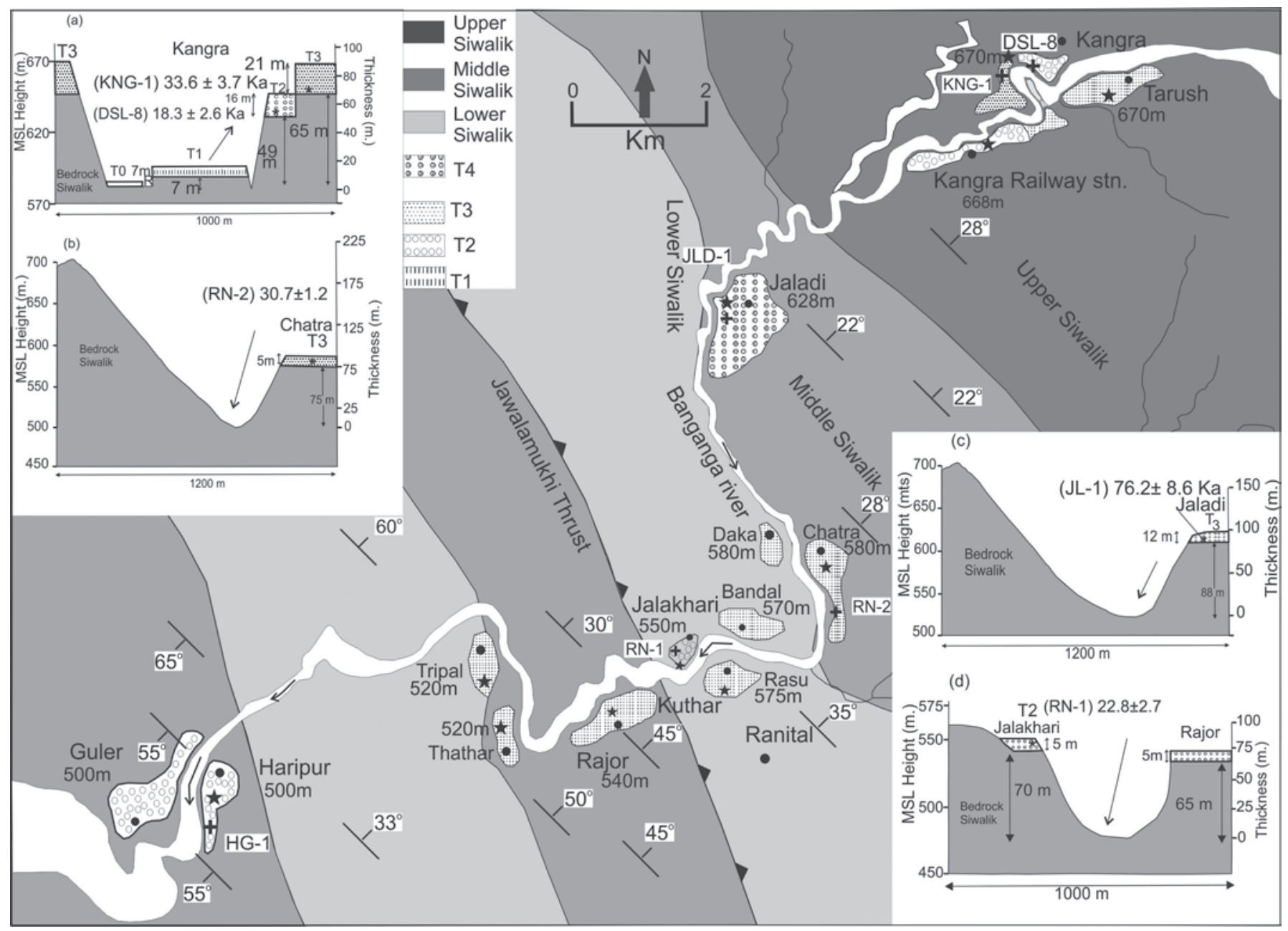

Figure 6. Geological map between Kangra and Guler, south of the K-Basin. Stippled areas show strath terraces along Baner (Banganga) river. The strath terraces are Kangra and Chatra on upper left inset, and Jaladi and Jalakhari on lower left inset. Dot-locality, Star-locality with elevation, Cross-OSL sample locality with sample number. Inset shows different strath terraces with thickness between river grade and strath surface and gravel cover, sample number and OSL age. Modified after Thakur et al. (2014).

Siwalik Boulder Conglomerate. This inference is corroborated with the presence of an unconformity between the consolidated Upper Siwalik Boulder Conglomerate and the overlying unconsolidated boulder bed and fan sediments of the K-Basin. The timing of the hiatus may be constrained between the age of 0.2 Ma of top part of the Boulder Conglomerate and the oldest OSL-dated (91 ka) unconsolidated fluvial boulder bed.

The structural and stratigraphic framework is continuous and same along the entire NW-SE trending D-Range. The K-Basin is developed south of the higher altitude, 5000-3000 m, segment of the D-Range. The basin has not extended to the south of the lower altitude western part of the Range. There is no structural feature observed to account for relative higher altitude of the eastern part of the D-Range. The higher altitude segment receives focused and highest precipitation. The instrumental recorded microseismicity in the region indicates dense clustering of events in the eastern part of the D-Range and the hinterland region, whereas microseismicity is much less pronounced in the western part (Kumar et al., 2009). The rupture zone of 1905 Kangra earthquake magnitude Mw 7.8 (Wallace et al., 2005) also lies in the eastern part. The distribution of microseismicity pattern, abrupt rise of the eastern D-Range with steep gradient to the south and tectonic setting indicate a ramp at mid- crustal level under the Range
(Fig. 1B) (Thakur et al., 2000; Kumar et al., 2009). It is envisaged that the D-Range grew as a whole length in a steady-state in initial stage that was in equilibrium with tectonic influx and erosional outflux up to a certain critical level sharing the same altitude. The formation of ramp was responsible for the higher altitude of the eastern DRange (Thakur, 1998). The erosion accelerated several times due to orographic enhancement of precipitation in the eastern parts with higher altitude during the last glacial cycle and the LGM glaciation. The occurrence of paleosols in the Kangra fan sediments, indicative of pedogenization, suggest warm-wet climate (Srivastava et al., 2009) with the onset of deglaciation. The deglaciation-induced erosion of the D-Range generated debris flow deposits into the K-Basin. Climateinduced erosion affects subsurface internal deformation leading to reorganization of fault system (Dahlen and Suppe, 1988; Whipple and Meade, 2006; Berger et al., 2008). Climate-induced enhanced erosion affected the internal deformation of the D-Range leading to contraction of the wedge and reactivation of the JT-MHT during Late Quaternary-Holocene. This appears to be currently reflected in microseismicity clusters and presence of the 1905 Kangra earthquake seismogenic zone at mid-crustal level of eastern part of the D-Range. The post Siwalik K-Basin, filled by eroded flux from the southern flank of the eastern D-Range, is developed over the hanging wall of 
the Jawalamukhi Thrust (JT). The K-Basin was formed as a piggyback basin during Late Quaternary, similar to the basin developed on the back of an active thrust (Ori and Friend, 1984). The occurrence of strath terraces on the hanging wall of the JT with their formation ages 76 ka to 18 ka suggest that the JT was active during Late Quaternary. The JT was developed as a foreland propagating foldthrust system south of the MBT. The strath terraces indicate uplift due to slip over the JT. The OSL ages of the strath surfaces point to reactivation ages of the JT during Late Quaternary. The K-basin depositional ages, 78-15 ka (Late Quaternary) correspond to the strath surface ages of the terraces above the JT. This implies that reactivation of the JT led to the formation of K-Basin, which is filled by sediments derived from the $\mathrm{D}$-Range due to the glaciation-deglaciation processes. It suggests that there is a temporal-spatial relationship between reactivation of the JT and formation of the $\mathrm{K}$-basin, that was coupled with climate induced erosion of the D-Range for its filling.

\section{Acknowledgements}

We thank Director, WIHG for the logistic support. The Department of Science and Technology, Government of India, provided the financial support to the project. MJ acknowledge Director, GBPNIHESD for his support.

\section{References}

Beaumont, C., Jamieson, R.A., Nguyen, M.H., and Lee, B., 2001, Himalayan tectonics explained by extrusion of a low-viscosity crustal channel coupled to focused surface denudation: Nature, v. 414, pp. 738-742.

Berger, A.L., Gulick, S.P.S., Sapotila, J.A., Upton, P., and other members., 2008, Quaternary tectonic response to intensified glacial erosion in an orogenic wedge: Nature Geoscience, v. 1, pp. 793-799.

Church, M.A., and Ryder, J.M., 1972, Paraglacial sedimentation: a consideration of fluvial processes conditioned by glaciations: Geological Society of America Bulletin, v. 83, pp. 3059-3071.

Dahlen, F.A., and Suppe, J., 1988, Mechanics, growth, and erosion of mountain belts. Processes in Continental Lithospheric Deformation: Geological Society of America, v. 218, pp.161-178.

DeCelles, P.G., Robinson, D.M., Quade, J., Ojha, T.P., Garzione, C.N., Copeland, P., and Upreti, B.N., 2001, Stratigraphy, structure, and tectonic evolution of the Himalayan fold-thrust belt in western Nepal: Tectonics, v. 20 (4), pp. 487-509.

Deeken, A., Thiede, R.C., Sobel, E.R., Hourigan, J.K., and Strecker, M.R., 2011, Exhumational variability within the Himalaya of northwest India: Earth and Planetary Science Letters, v. 305, pp. 103-114.

Dey, S., Thiede, R.C., Schildgen, T.F., Wittmann, H., Bookhagen, B., Scherler, D., Jain, V., and Strecker, M.R., 2016a, Climatedriven sediment aggradation and incision since the late Pleistocene in the NW Himalaya, India: Earth and Planetary Science Letters, v. 449, pp. 321-331.

Dey, S., Thiede, R.C., Schildgen, T.F., Wittmann, H., Bookhagen, B., Scherler, D., and Strecker, M. R., 2016b, Holocene internal shortening within the northwest Sub-Himalaya: Out-of-sequence faulting of the Jwalamukhi Thrust, India: Tectonics, v. 35 (11), pp. 2677-2697.

Hallet, B., Hunter, L., and Bogen, J., 1996, Rates of erosion and sediment evacuation by glaciers: A review of field data and their implications: Global and Planetary Change, v. 12, pp. 312-235.
Joshi, D.D., and Tandon, S.K., 1987, Quaternary valley-fill deposits of the Ravi drainage basin in Chamba, Western Himalaya: definition, lithostratigraphy and depositional framework: Journal of the Geological Society of India, v. 29, pp. 540-553.

Joshi, M., 2014, Climate-tectonic interaction in the morphogenic evolution of Ravi river basin in Chamba region, western Himachal Pradesh, NW Himalaya. Unpublished D. Phil. Thesis, Garhwal University, Srinagar.

Karunakaran, C., and Rao, R., 1979, Status of hydrocarbon in the Himalayan region: Contributions to stratigraphy and structure: Geological Survey of India, Miscellaneous Publication, v. 41, pp. 1-66.

Kumar, N., Sharma, J., Arora, B.R., and Mukhopadhyay, S., 2009, Seismotectonic model of the Kangra-Chamba sector of northwest Himalaya: constraints from joint hypocenter determination and focal mechanism: Bulletin of the Seismological Society of America, v. 99, pp. 1-15.

Murray, A.S., and Wintle, A.G., 2000, Luminescence dating of quartz using an improved single aliquot regenerative-dose protocol: Radiation measurements, v. 32(1), pp. 57-73.

Najman, Y., Bickle, M., Garzanti, E., Pringle, M., Barfod, D., Brozovic, N., Burbank, D., and Ando, S., 2009, Reconstructing the exhumation history of the Lesser Himalaya, NW India, from a multitechnique provenance study of the foreland basin Siwalik Group: Tectonics, v 28, Tc5018.

Ori, G.G., and Friend, F.P., 1984, Sedimentary basins formed and carried piggy back on active thrust sheets: Geology, v. 12, pp. 475-478.

Owen, L.A., Benn, D.I., Derbyshire, E., Evans, D.J.A., Mitchell, W.A. and Richardson, S., 1996, The Quaternary glacial history of the Lahul Himalaya, Northern India: Journal of Quaternary Science, v. 11 (1), pp. 25-42.

Owen, L.A., Bailey, R.M., and Rhodes, E.J., 1997, Style and timing of glaciation in the Lahul Himalaya, northern India: a framework for reconstructing Late Quaternary palaeoclimatic change in the western Himalayas: Journal of Quaternary Science, v. 12, pp. 83109.

Owen, L.A., Finkel, R.C., and Caffee, M.W., 2002, A note on the extent of glaciation in the Himalaya during the global Last Glacial Maximum: Quaternary Science Review, v. 21, pp. 147-158.

Powers, P.M., Lillie, R.J., and Yeats, R.S., 1998, Structure and shortening of Kangra and Dehradun re-entrants, sub-Himalaya, India: Geological Society of American Bulletin, v. 110, pp. 10101027.

Ranga Rao, A., Agarwal, R.P., Sharma, U.N., Bhalla, M.S., and Nanda, A.C., 1988, Magnetic polarity stratigraphy and vertebrate paleontology of upper Siwalik of the Jammu Hills: Journal of Geological Society of India, v. 32, pp. 109-128.

Robinson, D.M., DeCelles, P.G., and Copeland, P., 2006, Tectonic evolution of the Himalayan thrust belt in western Nepal: Geological Society of American Bulletin, v. 118, pp. 865-885.

Ryder, J.M., 1971a, Some aspects of the morphology of paraglacial alluvial fans in south-Central British Columbia: Canadian Journal of Earth Sciences, v. 8, pp. 1252-1264.

Ryder, J.M., 1971b, The stratigraphy and morphology of paraglacial alluvial fans in south-central British Columbia: Canadian Journal of Earth Sciences v. 8, pp. 279-298.

Sah, M.P., and Srivastava, R.A.K., 1992, Morphology and facies of the alluvial fan sedimentation in the Kangra valley, Himachal Himalaya: Sedimentary Geology, v. 76, pp. 23-42.

Sangode, S.J., Kumar, R., and Ghosh, S.K., 2003, Magnetic polarity stratigraphy of the Late Miocene Siwalik Group sediments from Kangra Re-entrant, H.P. India: Himalayan Geology, v. 24 (1), pp. 47-61. 
Sharma, K.K., and Bandooni, S.K., 2007, Data base for mitigatio and management of earthquake and landslides (Geohazard) on GIS platform using space technology for Kangra, Mandi, Hamirpur and Una districts of Himachal Pradesh. Project Report, DST, New Delhi.

Schelling, D., and Arita K., 1991, Thrusts tectonics, crustal shortening and the structure of the far Eastern Nepal Himalaya, Tectonics, v. 10, pp. 851-862.

Srivastava, P., Rajak, M.K., and Singh, L.P., 2009, Late Quaternary alluvial fans and palaeosole of the K-Basin, NW Himalaya: tectonic and palaeoclimatic implication: Catena, v. 76, pp. 135154.

Thakur, V.C., 1998, Structure of the Chamba nappe and position of the Main Central Thrust in Kashmir Himalaya: Journal of Asian Earth Science, v. 16, pp. 269-282.

Thakur, V.C., Joshi, M., Sahoo, D., Suresh, N., Jayangondapermal, R., and Singh, A., 2014, Partitioning of convergence in Northwest Sub-Himalaya: estimation of late Quaternary uplift and convergence rates across the Kangra reentrant, North India: International Journal of Earth Sciences, v. 103(4), pp. 1037-1056.

Thakur, V.C., Sriram, V., and Mundepi, A.K., 2000, Seismotectonics

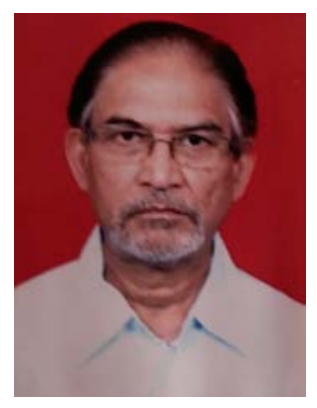

Dr. Vikram C. Thakur is M.Sc. (Panjab) and Ph.D. DIC (Imperial College, London). He is former Director, Wadia Institute of Himalayan Geology, Dehradun and CSIR Emeritus Scientist. Dr. Thakur is a Fellow of Indian Academy of Sciences, recipient of National Mineral Award and Padama Shree awardee. He has contributed on the regional framework and tectonics of suture zone of Ladakh and Arunachal, structure of Chamba nappe sequence, and active tectonics of NW Sub Himalaya. Authored a book on "Geology of Western Himalaya", Pergamon Press, and co-authored the recent book "Active tectonics of Kumaun and Garhwal Himalaya”, Springer.

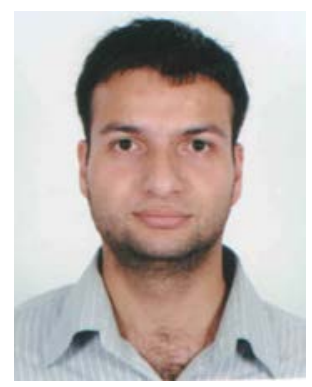

Dr. Mayank Joshi obtained Post Graduation from Kumaun University and Ph.D. from Wadia Institute of Himalayan Geology, India. His Ph.D work was focused on the Quaternary landform evolution in Chamba nappe and active tectonics of the region. His work includes tectonic Geomorphology, Quaternary landform evolution in Himalayan region, climate change and societal disturbances with special on people perceptions. His other expertise includes landslide and subsidence studies, Hydro-geology, achaeo-seismology for earthquake hazards assessment. of the great 1905 Kangra earthquake meizoseismal region in Kangra-Chamba, NW Himalaya: Tectonophysics, v. 326(3), 289298.

Thiede, R.C., Bookhagen, B., Arrowsmith, J.R., Sobel, E.R., and Strecker, M.R., 2004, Climatic control on rapid exhumation along the southern Himalayan Front: Earth and Planetary Science Letter, v. 222, pp. 791-806.

Wallace, K., Bilham, R., Blume, F., Gaur, V.K., and Gahalaut, V., 2005, Surface deformation in the region of the 1905 Kangra $\mathrm{Mw}=7.8$ earthquake in the period 1846-2001: Geophysical Research Letters, v. 32, L15307.

Whipple, K.X., and Meade, B.J., 2006, Orogen response to changes in climatic and tectonic forcing: Earth and Planetary Science Letter, v. 243, pp. 218-228.

Wobus, C.W., Hodges, K.V., and Whipple, K.X., 2003, Has focused denudation sustained active thrusting at the Himalayan topographic front?:Geology, v. 31, pp. 861-864.

Yin, A., 2006, Cenozoic tectonic evolution of the Himalayan orogen as constrained by along-strike variation of structural geometry, exhumation history, and foreland sedimentation: Earth Science Review, v. 76, pp. 1-131.

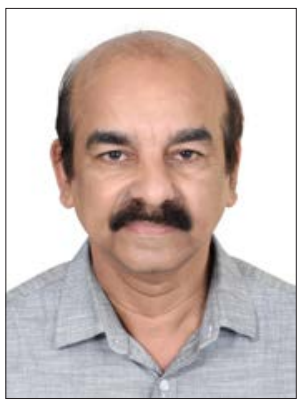

Dr. Suresh Narayanapanicker has graduated from Kerala University and obtained his post graduation from Cochin University of Science and Technology, India.He carried out the Ph.D work from 1989-1993 at Wadia Institute of Himalayan Geology (WIHG), Dehradun, and obtained the degree from HNB Garhwal University, India. His PhD work is Sediment Dispersal in the Bay of Bengal with special emphasis on mineralogy and geochemistry. His postdoctoral work includes evolution of Quaternary alluvial fans and fluvial deposits and active tectonic studies.

He joined the sedimentology Group of WIHG in 2005 as Scientist.Hiswork includes sedimentology and luminescence dating of alluvial fans and fluvial deposits in the Himalaya, particularly from the 'Duns' in the Sub-Himalaya. His other expertise includes clay mineral analysis, active tectonic studies, paleoseismicityand trench excavation survey for earthquake hazard assessment. He is an expert in luminescence dating technique and clay mineral studies and looking after these labs at WIHG. 